Journal of Bangladesh Academy of Sciences, Vol. 35, No. 2, 237-240, 2011

\title{
PROBIOTIC TECHNOLOGY : AN EFFECTIVE MEANS FOR BIOREMEDIATION IN SHRIMP FARMING PONDS
}

\author{
ARUN KUMAR JHA* \\ Massawa College of Marine Science \& Technology, Massawa, Northern Red Sea Region, \\ Eritrea (N.E. Africa)
}

\begin{abstract}
In most of the shrimp farming ponds deterioration of water quality, pond bottom condition, incidence of toxic gases like $\mathrm{NH}_{3}, \mathrm{NO}_{2}, \mathrm{H}_{2} \mathrm{~S}$ etc. and occurrence of disease appear generally after 60 days of farming onwards. As a remedial measure, application of probiotics as a biotechnological tool for bioremediation has been suggested for shrimp farm located in a Srijang village near Chandipur area of coastal Balasore, Orissa, (India) and was found to be effective in controlling and reducing of pathogenic vibrio population and toxic gases.
\end{abstract}

Key words: Probiotics, Shrimp, Aquaculture, Bioremediation, Diseases, Toxic gases

\section{INTRODUCTION}

One of the major problems at present in the shrimp aquaculture is the microbial disease caused due to self pond pollution. The application of antibiotics is of no use due to emergence of antibacterial resistance and increased disease resistance in aquatic pathogens. As an alternative measure to control pollution and disease the use of probiotics for sustainable and eco-friendly aquaculture is gaining acceptance.

During the culture operations as days of culture increases, the shrimp biomass and feed input also increase, as such the pond bottom gets deteriorated by left over feed due to excess feeding, fecal matter and dead algae. With the increase in shrimp biomass, the culture environment becomes unstable and prone to rapid changes in water quality conditions. Therefore, water quality has to be monitored and managed since it has an impact on health and survival of shrimps. Exposure of shrimps to toxic gases like $\mathrm{NH}_{3}$, $\mathrm{NO}_{2}$ and $\mathrm{H}_{2} \mathrm{~S}$ leads to stress and ultimately disease. The outbreak of disease is mainly due to deteriorated water and soil conditions. Implementation of probiotic technology would be effective for the process of bioremediation in shrimp aquaculture ponds.

\section{MATERIALS AND METHODS}

A tiger shrimp farm situated in coastal Balasore of Orissa (India) at Srijang village near Chandipur area located at $21^{\circ} 32$ 'NL and $86.54^{\circ} \mathrm{EL}$ was selected for the study purpose. Two ponds of size $4000 \mathrm{~m}^{2}$ each with a stocking density of $10 \mathrm{shrimps} / \mathrm{m}^{2}$ were

*Corresponding author: <jhaarun1@yahoo.co.in>. 
taken for experimental study purpose. Commercially available environmental pond probiotic, namely Environ-AC from Biostadt India Ltd. was used as a bio-remediate for pond treatment. Environ-AC consists of a consortia of large number of selective, nonpathogenic, beneficial, native micro-organisms such as species of Bacillus, Lactobacillus, Nitrosomas, Nitrobacter etc. which are bio-fixed on a highly porous and natural material called cocolith, available in powder granular form, with a concentration of $1 \times 10^{8}$ $\mathrm{CFU} / \mathrm{gm}$.

Generally in the initial period of culture, there is not much water quality problem due to low level of biomass in the pond. But when the shrimp grows and higher quantity of feed is added into the pond, the water quality deteriorates due to increased metabolic waste and excess of feed waste. After noticing deterioration in the pond environmental condition, probiotic treatment started from 70 DOC (days of culture) onwards, and it was applied with an initial dosage of $10 \mathrm{~kg}$ followed by $4 \mathrm{~kg}$ at a regular interval of every 10 days till the crop end. Water samples were collected before probiotic treatment as well as after treatment and subjected to microbial analysis for estimation of Vibrio population and analysis of toxic gases like ammonia, nitrite and hydrogen sulphide.

\section{RESULTS AND DISCUSSION}

After 60 - 65 DOC it was noticed that formation of organic sludge had taken place at the pond bottom and the pond environmental condition had started degrading. Water sample analysis prior to probiotic treatment had shown the presence of $\mathrm{NH}_{3}, \mathrm{NO}_{2}$ and $\mathrm{H}_{2} \mathrm{~S}$ as well as high population of Vibrio pathogens. Whereas after probiotic treatment from 70 DOC onwards reducing in level of toxic gases was observed which completely reduced to nil as well as suppression of Vibrio population was noticed. The results are given in Table 1.

Table 1. Effectiveness of probiotics in reducing toxic gases and pathogenic Vibrio population in shrimp ponds.

\begin{tabular}{lllll}
\hline \multirow{2}{*}{ Parameters } & \multicolumn{2}{c}{ Pond 1 } & \multicolumn{2}{c}{ Pond 2 } \\
\cline { 2 - 5 } & Before treatment & After treatment & Before treatment & After treatment \\
\hline $\mathrm{NH}_{3}(\mathrm{ppm})$ & 0.3 & Nil & 0.25 & Nil \\
$\mathrm{H}_{2} \mathrm{~S} "$ & 0.1 & Nil & 0.09 & Nil \\
$\mathrm{NO}_{2} "$ & 0.25 & Nil & 0.32 & Nil \\
Vibrio & Green & Green & Green & Green \\
Population & Colonies $=150$ & Colonies $=70$ & Colonies $=160$ & Colonies = 80 \\
CFU/ml & Yellow & Yellow & Yellow & Yellow \\
& colonies $=320$ & colonies $=240$ & colonies $=350$ & colonies = 260 \\
\hline
\end{tabular}

The study clearly indicated that probiotics are effective in bioremediation for shrimp aquaculture ponds. Usage of probiotics reduceed and prevents the accumulation of 
organic sludge at pond bottom as well as formation of toxic gases like $\mathrm{NH}_{3}, \mathrm{NO}_{2}, \mathrm{H}_{2} \mathrm{~S}$ etc., it was also effective in controlling of Vibrio population and thus helped to improve water quality and subsequently shrimp health.

These findings are similar to the observations made by Ravichandran and Jallaluddin (2000), who used Environ - AC $25 \mathrm{Kg} / \mathrm{ha}$ as an initial dosage followed by $10 \mathrm{Kg}$ at weekly interval. In their studies they showed that in probiotic treated ponds there was only gradual increase of Vibrio populations whereas in untreated pond high level of Vibrio count was reached. Prabhu et al. (1999) showed in their studies the less level of ammonia and nitrite in the probiotic-treated pond, whereas steady built up of the same in control ponds. Jha and Naik $(2007,2008,2009 \mathrm{a}$ and 2009b) in their studies showed that probiotic-treated pond had less incidence of Vibrio bacteria and no formation of toxic gases like ammonia, nitrite hydrogen sulphide etc., whereas in untreated control ponds there was increase of Vibrio population and steady built up of toxic gases. All these authors recommended the usage of probiotics in shrimp farms for decomposition of organic matter, reducing and controlling of pathogenic Vibrio bacteria and toxic metabolites, and thus maintaining a suitable environmental pond condition for better survival and yield of shrimp.

\section{CONCLUSION}

The implementation of microbial biotechnology i.e. the usage of probiotics to enhance and maintain aquaculture production level is now gaining acceptance as a better, cheaper and more effective remedy than the use of antibiotics. Antibiotics and other chemicals cannot be used for long time to compensate declining water quality and environmental conditions in shrimp culture ponds. Thus, for bioremediation, an ecological approach can be a better option for the development of sustainable aquaculture.

\section{ACKNOWLEDGEMENTS}

The author thanks Prof. B. N. Naik, former Dean, faculty of Sciences \& Head, Dept. of Environmental Sciences, Fakir Mohan University, Balasore, Orissa, (India) for reviewing the manuscript.

\section{REFERENCES}

Jha, A.K. and B.N. Naik. 2007. Incidence of protozoan fouling in shrimp Penaeus monodon grow-out culture are commonly in association, with the poor pond environmental condition. Bull. Env. Sci. 25(1): 41-43.

Jha, A.K. and B.N. Naik. 2008. Bioremediation : An emerging microbial biotechnology for sustainable aquaculture. Aqua international, pp. 19-20.

Jha, A.K. and B.N. Naik. 2009a. Probiotic technology : An alternative approach to antibiotic treatment in aquaculture. Aquaculture Europe 34(1): 22-23. 
Jha, A.K. and B.N. Naik. 2009b. Microbial Biotechnology : An effective means for disease prevention in shrimp farming ponds. Fishing chimes 29(3): 39-40.

Prabhu, N. M., A. R. Nazar, S. Rajagopal, and S.A. Khan. 1999. Use of probiotics in water quality management during shrimp culture. J. Aquatic. Trop. 14(3): 227-236.

Ravichandran, R. and R.S. Jalaluddin. 2000. Stress management strategy with probiotics for preventing shrimp diseases. First Indian Fish. Sci. Congress. Sept, 21-23 2000, Chandigarh: 112.

(Received revised manuscript on 22 October, 2011) 